\title{
Characterization of a Cell-surface Protein Antigen of Hydrophilic Streptococcus mutans Strain GS-5
}

\author{
By HIROTAKA OHTA, HIROHISA KATO, NOBUO OKAHASHI, \\ ICHIRO TAKAHASHI, SHIGEYUKI HAMADA $\dagger$ AND TOSHIHIKO KOGA* \\ Department of Dental Research, National Institute of Health, 2-10-35 Kamiosaki, Shinagawa-ku, \\ Tokyo 141, Japan
}

(Received 30 June 1988; revised 15 November 1988; accepted 5 December 1988)

\begin{abstract}
Fourteen strains of Streptococcus mutans serotype $c$ were examined for their cell-surface protein antigens in terms of hydrophobicity, $M_{\mathrm{r}}$ and immunochemical specificities. Thirteen strains were hydrophobic, while strain GS-5 was markedly hydrophilic as compared to the other strains tested. Cell-surface protein antigens were then analysed by sodium dodecyl sulphatepolyacrylamide gel electrophoresis (SDS-PAGE) and Western immunoblotting. A protein antigen of $M_{\mathrm{r}} 190000(\mathrm{PAc})$ was found in cell extracts and culture supernatants of all the hydrophobic strains. Neither culture supernatant nor cell extract of strain GS-5 contained PAc. Strain GS-5, however, produced extracellularly a large amount of a protein of $M_{\mathrm{r}} 155000$ (PAGS-5) which reacted with rabbit anti-PAc serum. Immunodiffusion analysis showed that PAGS-5 lacked a part of the antigenic moieties in the PAc molecule. SDS-PAGE and radioimmunoassay showed a small amount of PAGS-5 on the cell surface of strain GS-5. These findings suggest that PAGS-5 may correspond to PAc which lacks a region participating in binding of PAc to the streptococcal cell.
\end{abstract}

\section{INTRODUCTION}

Streptococcus mutans has been strongly implicated as a causative organism of dental caries (Hamada \& Slade, 1980; Loesche, 1986). The organism possesses various kinds of cell-surface polymers such as proteinaceous antigens, serotype-specific polysaccharide antigens, lipoteichoic acid and peptidoglycan (Hamada \& Slade, 1980). Among these cell-surface polymers, much attention has been focused on a high- $M_{\mathrm{r}}$ protein antigen that has been variously designated as antigen B (Russell, 1979), I/II (Russell et al., 1980), IF (Hughes et al., 1980) and P1 (Forester et al., 1983). Streptococcus sobrinus also possesses a cell-surface protein antigen that is immunologically and biochemically similar to that of $S$. mutans (Moro \& Russell, 1983; Holt et al., 1982; Okahashi et al., 1986).

The high- $M_{\mathrm{r}}$ protein antigen of $S$. mutans serotype $c$ (PAc) is an effective vaccine antigen for prevention of dental caries in monkeys (Lehner et al., 1981; Russell et al., 1982). Local passive immunization with monoclonal antibodies raised against PAc prevents the colonization by $S$. mutans of animal and human tooth surfaces (Lehner et al., 1985; Ma et al., 1987). Polyclonal antibodies to PAc are strongly opsonic for S. mutans (Scully et al., 1980). McBride et al. (1984) suggested that location of PAc on the streptococcal surface is important in forming hydrophobic bonds with hydrophobic regions of salivary pellicle. The organization of PAc on the cell surface, however, is poorly understood.

$\dagger$ Present address: Department of Oral Microbiology, Osaka University Faculty of Dentistry, 1-8 Yamadaoka, Suita, Osaka 565, Japan.

Abbreviations: PAc, an $M_{\mathrm{r}} 190000$ protein antigen of $S$. mutans serotype $c$; PAGS-5, an $M_{\mathrm{r}} 155000$ protein antigen of $S$. mutans strain GS-5. 
In the present study we examined the location of PAc on cell surfaces of various strains of $S$. mutans serotype $c$ and their cell hydrophobicity.

\section{METHODS}

Bacterial strains. Serotype $c S$. mutans strains GS-5, Ingbritt, MT6R, MT12, MT118R, MT8148, MT6801, NG7183, OMZ70, P2, C67-1, C67-25, NCTC 10449R and NCTC 10449S were used in this study. These strains were selected from the stock culture collection in the Department of Dental Research, National Institute of Health, Tokyo, Japan.

$S D S-P A G E$. S. mutans strains were grown at $37^{\circ} \mathrm{C}$ for $18 \mathrm{~h}$ in diffusate medium of Brain Heart Infusion (BHI; Difco) broth. The cell-free culture supernatant was collected by centrifugation at $10000 \mathrm{~g}$ for $20 \mathrm{~min}$ at $4{ }^{\circ} \mathrm{C}$. Extracellular proteins were precipitated from the culture supernatant by adding solid ammonium sulphate to $60 \%$ saturation. The precipitate was collected by centrifugation, dissolved in distilled water, dialysed against distilled water, and lyophilized. The dried culture supernatant, and whole cells $\left(50 \mathrm{mg}\right.$ dry weight $\left.\mathrm{ml}^{-1}\right)$, were suspended separately in $10 \mathrm{~mm}$-Tris/ $\mathrm{HCl}$ buffer, $\mathrm{pH} \mathrm{6.8,} \mathrm{containing} 8 \mathrm{M}$-urea, $1 \%$ (w/v) SDS and $1 \%(\mathrm{v} / \mathrm{v}) 2-$ mercaptoethanol, and heated at $100^{\circ} \mathrm{C}$ for $3 \mathrm{~min}$. The cell extract was then clarified by centrifugation. SDSpolyacrylamide slab gels were prepared as described by Laemmli (1970). The culture supernatant ( $0.5 \mathrm{mg}$ protein) and the cell extract $(60 \mu \mathrm{l})$ were electrophoresed at $7.5 \mathrm{~mA}$ per gel at room temperature for $12 \mathrm{~h}$ using a $7.5 \%(\mathrm{w} / \mathrm{v})$ resolving and a $3 \%(\mathrm{w} / \mathrm{v})$ stacking gel $(14 \times 11 \times 0.2 \mathrm{~cm})$ containing $0.1 \%(\mathrm{w} / \mathrm{v})$ SDS. Catalase $\left(M_{\mathrm{r}} 60000\right)$, bovine serum albumin (67000), phosphorylase $b$ (94000) and ferritin (220000) were used as $M_{\mathrm{r}}$ standards. Proteins were stained with Coomassie brilliant blue R-250.

Antisera. Anti-PAc serum and anti-PAGS-5 serum were prepared as follows. The concentrated culture supernatants of strains MT8148 and GS-5 were electrophoresed on SDS-polyacrylamide slab gels as described above, and bands corresponding to proteins of $M_{\mathrm{r}} 190000$ (PAc) and $M_{\mathrm{r}} 155000$ (PAGS-5), respectively, were carefully cut out to avoid any contamination. The gel pieces containing each protein were suspended in phosphatebuffered saline (PBS; pH 7.5), and crushed in a porcelain mortar. The crushed gel suspensions (about $0.2 \mathrm{mg}$ protein $\mathrm{ml}^{-1}$ ) were emulsified with an equal volume of Freund's complete adjuvant (Difco). New Zealand White rabbits were immunized intramuscularly with the emulsions $(1 \mathrm{ml})$, followed 2 weeks later by intramuscular injection of $0.5 \mathrm{ml}$ of the crushed gel suspensions (about $0.2 \mathrm{mg}$ protein $\mathrm{ml}^{-1}$ ). Blood was taken 3 weeks after the last immunization.

Western blotting. The culture supernatant $(0 \cdot 1 \mathrm{mg}$ protein) and the cell extract $(12 \mu \mathrm{l})$ were electrophoresed in SDS-polyacrylamide slab gels as described above, and transferred to a nitrocellulose sheet by the Western blotting technique (Burnette, 1981). The sheet was treated with anti-PAc serum. The antibody bound to the immobilized replica proteins on the sheet was detected by solid-phase immunoassay with horseradish peroxidase-conjugated goat anti-rabbit immunoglobulin G (Koga et al., 1986).

Radioimmunoassay. S. mutans strains were grown at $37^{\circ} \mathrm{C}$ for $18 \mathrm{~h}$ in BHI broth. The cells were harvested by centrifugation, and washed twice in PBS. The washed cells $\left(5 \times 10^{7}\right)$ were allowed to react with anti-PAc serum $(1 \mu \mathrm{l})$ or anti-PAGS-5 serum $(1 \mu \mathrm{l})$ in $0.15 \mathrm{ml}$ PBS containing $1 \%(\mathrm{w} / \mathrm{v})$ bovine serum albumin for $1 \mathrm{~h}$ at room temperature (Kato et al., 1986). After being washed three times in PBS by centrifugation, the cells were allowed to react with $1 \mu 1^{125}$ I-labelled goat anti-rabbit immunoglobulin G (ICN Radiochemicals) in $50 \mu \mathrm{l}$ PBS containing $1 \%(\mathrm{w} / \mathrm{v})$ bovine serum albumin. After incubation for $1 \mathrm{~h}$ at room temperature, the cells were washed three times in PBS. The radioactivity associated with the cells was then determined.

Immunodiffusion. Agar gel diffusion was performed in 1\%(w/v) agarose gel in $15 \mathrm{~mm}$-barbital hydrochloride buffer, $\mathrm{pH} 8 \cdot 6$, containing $1 \%(\mathrm{v} / \mathrm{v})$ Triton $\mathrm{X}-100$. The agar plates were washed with PBS, dried and stained with Coomassie brilliant blue R-250.

Hydrophobicity. S. mutans strains were grown at $37^{\circ} \mathrm{C}$ for $18 \mathrm{~h}$ in $\mathrm{BHI}$ broth. The relative surface hydrophobicity of the cells was determined by their adsorption to hexadecane and their aggregation in salt solution as described by Koga et al. (1986).

Preparation of PAC. PAc was prepared from the culture supernatant of $S$. mutans MT8148 grown in diffusate medium of BHI broth by ammonium sulphate precipitation, chromatography on diethylaminoethyl-Sephacel (Pharmacia), and subsequent gel filtration on Sepharose CL-6B (Pharmacia) (Russell et al., 1980).

\section{RESULTS}

Surface hydrophobicity. Cell-surface hydrophobicity of the 14 serotype $c S$. mutans strains was determined by their adsorption to hexadecane and their aggregation in ammonium sulphate. The surface hydrophobicity of strain GS-5 was markedly lower than that of other strains (Table 1). 
Table 1. Hydrophobicity of strains of $S$. mutans serotype $c$

The relative surface hydrophobicity of $S$. mutans cells was determined by their adsorption to hexadecane and their aggregation in salt. The bacterial suspension $(3 \mathrm{ml})$ was mixed with $300 \mu$ l hexadecane. Adsorption was calculated as the percentage loss in optical density relative to that of the initial cell suspension; values are the mean \pm SD of triplicate assays. Bacterial aggregation in salt is expressed as the lowest ammonium sulphate concentration (M) causing bacterial aggregation.

\begin{tabular}{|c|c|c|c|c|c|}
\hline \multirow[b]{2}{*}{ Strain } & \multicolumn{2}{|c|}{ Hydrophobicity } & & \multicolumn{2}{|c|}{ Hydrophobicity } \\
\hline & $\begin{array}{c}\text { Bacterial } \\
\text { adsorption } \\
\text { to hexadecane }\end{array}$ & $\begin{array}{l}\text { Bacterial } \\
\text { aggregation } \\
\text { (M) }\end{array}$ & Strain & $\begin{array}{c}\text { Bacterial } \\
\text { adsorption } \\
\text { to hexadecane }\end{array}$ & $\begin{array}{l}\text { Bacterial } \\
\text { aggregation } \\
\text { (M) }\end{array}$ \\
\hline GS-5 & $4.9 \pm 0.3$ & $>2 \cdot 0$ & P2 & $25 \cdot 0 \pm 6 \cdot 3$ & $1 \cdot 1$ \\
\hline Ingbritt & $29 \cdot 0 \pm 2 \cdot 5$ & $1 \cdot 1$ & C67-1 & $42 \cdot 5 \pm 3 \cdot 3$ & $1 \cdot 0$ \\
\hline MT6R & $25.9 \pm 1.7$ & $1 \cdot 2$ & C67-25 & $25 \cdot 7 \pm 2 \cdot 6$ & $1 \cdot 2$ \\
\hline MT12 & $27.9 \pm 5 \cdot 6$ & $1 \cdot 2$ & MT6801 & $23 \cdot 1 \pm 1 \cdot 8$ & $1 \cdot 2$ \\
\hline MT118R & $27 \cdot 6 \pm 1.9$ & $1 \cdot 2$ & NG7183 & $32 \cdot 2 \pm 2 \cdot 4$ & $1 \cdot 1$ \\
\hline MT8148 & $24.9 \pm 2 \cdot 6$ & $1 \cdot 2$ & NCTC $10449 R$ & $24 \cdot 2 \pm 1 \cdot 5$ & $1 \cdot 2$ \\
\hline OMZ70 & $42 \cdot 5 \pm 1 \cdot 7$ & 1.0 & NCTC $10449 S$ & $43.8 \pm 4.8$ & 1.0 \\
\hline
\end{tabular}

SDS-PAGE analysis of culture supernatants and whole cells. Culture supernatants of the 14 strains of $S$. mutans serotype $c$ were analysed by SDS-PAGE and Western blotting. Gels stained with Coomassie brilliant blue showed that culture supernatants of all the strains, except strain GS-5, possessed a protein of $M_{\mathrm{r}} 190000$ (PAc) (Fig. 1a). PAc was not found in the culture supernatant of strain GS-5, but this strain produced extracellularly a large amount of a protein of $M_{\mathrm{r}} 155000$ (PAGS-5). The band of PAGS-5, as well as that of PAc, reacted with rabbit anti-PAc serum (Fig. $1 b$ ). SDS-PAGE analysis of urea/SDS extracts from whole cells of $S$. mutans serotype $c$ is shown in Fig. 2. Cell extract of strain GS-5 did not contain PAc, which was present in all the other strains, but contained a small amount of the $M_{\mathrm{r}} 155000$ protein (PAGS-5) that reacted with anti-PAc serum. When culture supernatants and cell extracts of $S$. mutans serotype $c$ were analysed by Western blotting, a number of other protein bands with lower $M_{\mathrm{r}}$, as well as PAc and PAGS-5, reacted with anti-PAc serum. The appearance of these lower- $M_{\mathrm{r}}$ proteins may have resulted from different degrees of proteolysis of PAc and PAGS-5 by endogenous proteases of $S$. mutans.

Immunological comparison of PAc and PAGS-5. Immunological specificity of PAc and PAGS-5 was investigated by immunodiffusion. Inımunodiffusion tests revealed that a single precipitin band formed between PAc and anti-PAc serum (Fig. $3 a$ ). This band was fused with that produced between anti-PAc serum and the culture supernatants of strains MT8148 and Ingbritt, but gave a spur with that produced between anti-PAc serum and the culture supernatant of strain GS-5. On the other hand, the culture supernatants of strains MT8148 and GS-5 formed a precipitin line of identity with anti-PAGS-5 serum (Fig. $3 b$ ). These results indicated that PAGS-5 lacked a part of the antigenic moieties in the PAc molecule.

Reactivity of $S$. mutans cells with anti-PAC serum and anti-PAGS-5 serum. The amount of cellsurface antigens with which anti-PAc serum or anti-PAGS- 5 serum reacted was determined by radioimmunoassay. Compared with other strains, the amount of cell-surface antigens of strain GS-5 with which anti-PAc serum and anti-PAGS-5 serum reacted was very small (Table 2). Reactivity of whole cells of $S$. mutans strains used in this study with anti-PAc and anti-PAGS-5 sera and their surface hydrophobicity were not apparently correlated (Tables 1 and 2). 


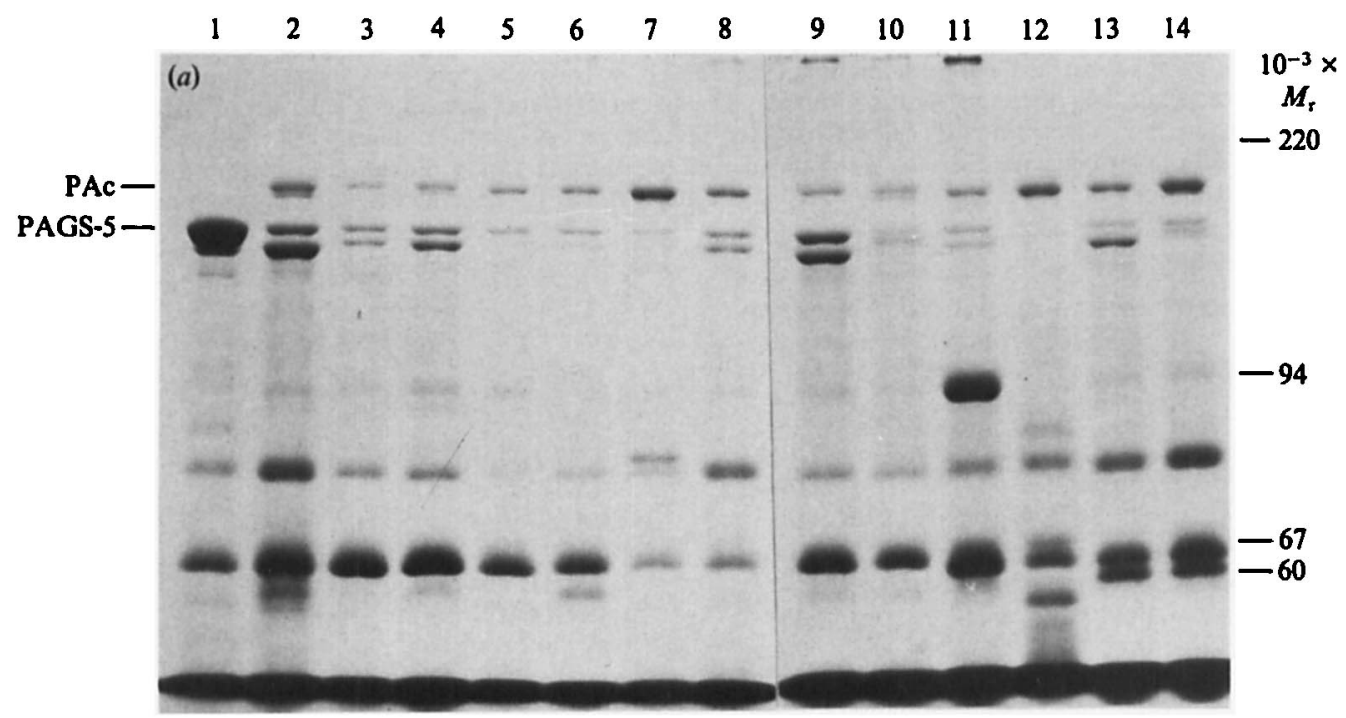

(b)

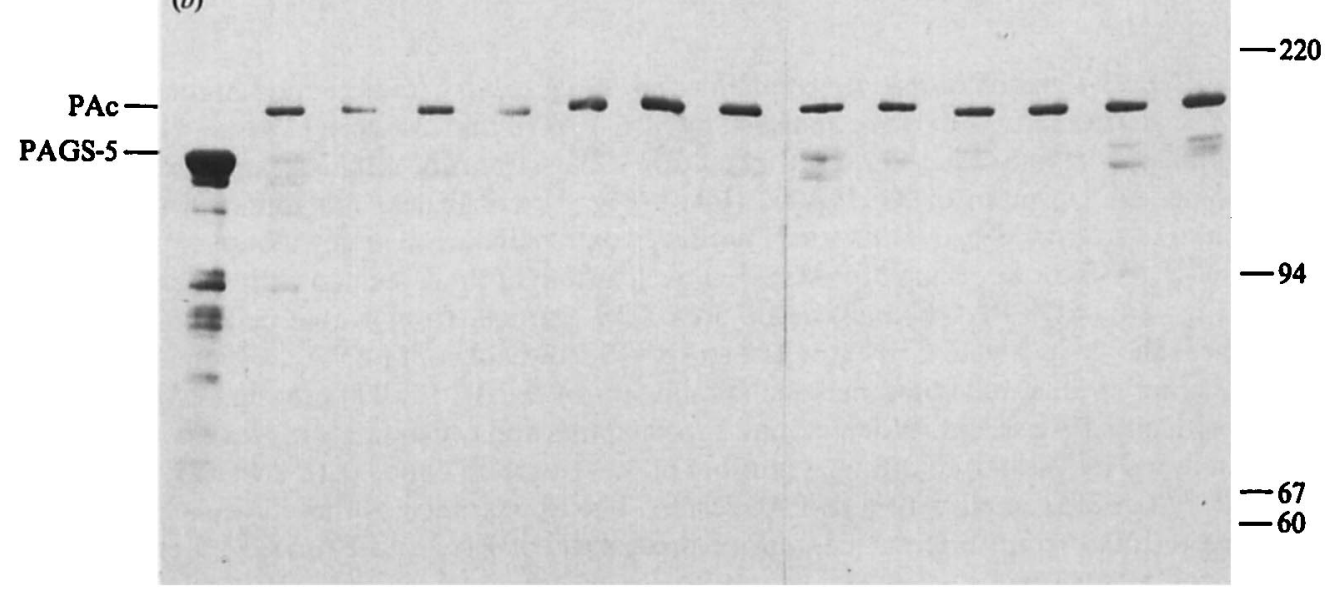

Fig. 1. SDS-PAGE and Western blotting of culture supernatants of serotype $c S$. mutans strains. Culture supernatants were concentrated by ammonium sulphate precipitation, and analysed by SDSPAGE. (a) Gel stained with Coomassie brilliant blue. (b) Anti-PAc serum bound to immobilized antigens on a nitrocellulose sheet transferred by an electrophoretic blotting procedure. The antibody was detected by solid-phase immunoassay with horseradish peroxidase-conjugated goat anti-rabbit immunoglobulin G. The $M_{\mathrm{r}}$ markers used were catalase $\left(M_{\mathrm{r}} 60000\right)$, bovine serum albumin (67000), phosphorylase $b(94000)$ and ferritin (220000). Lane 1, strain GS-5; lane 2, strain Ingbritt; lane 3, strain MT6R; lane 4, strain MT12; lane 5, strain MT118R; lane 6, strain MT8148; lane 7, strain OMZ70; lane 8, strain P2; lane 9, strain C67-1; lane 10, strain C67-25; lane 11, strain MT6801; lane 12, strain NG7183; lane 13, strain NCTC 10449R; lane 14, strain NCTC 10449S.

\section{DISCUSSION}

In this study, we showed the presence of PAc of $M_{\mathrm{r}} 190000$ in culture supernatants and cell extracts of all the strains, except strain GS-5, of $S$. mutans serotype $c$ tested. No PAc was detected in either the culture supernatant or the cell extract of hydrophilic strain GS-5, but this strain produced in the culture supernatant a large amount of PAGS-5 of $M_{\mathrm{r}} 155000$ reactive 


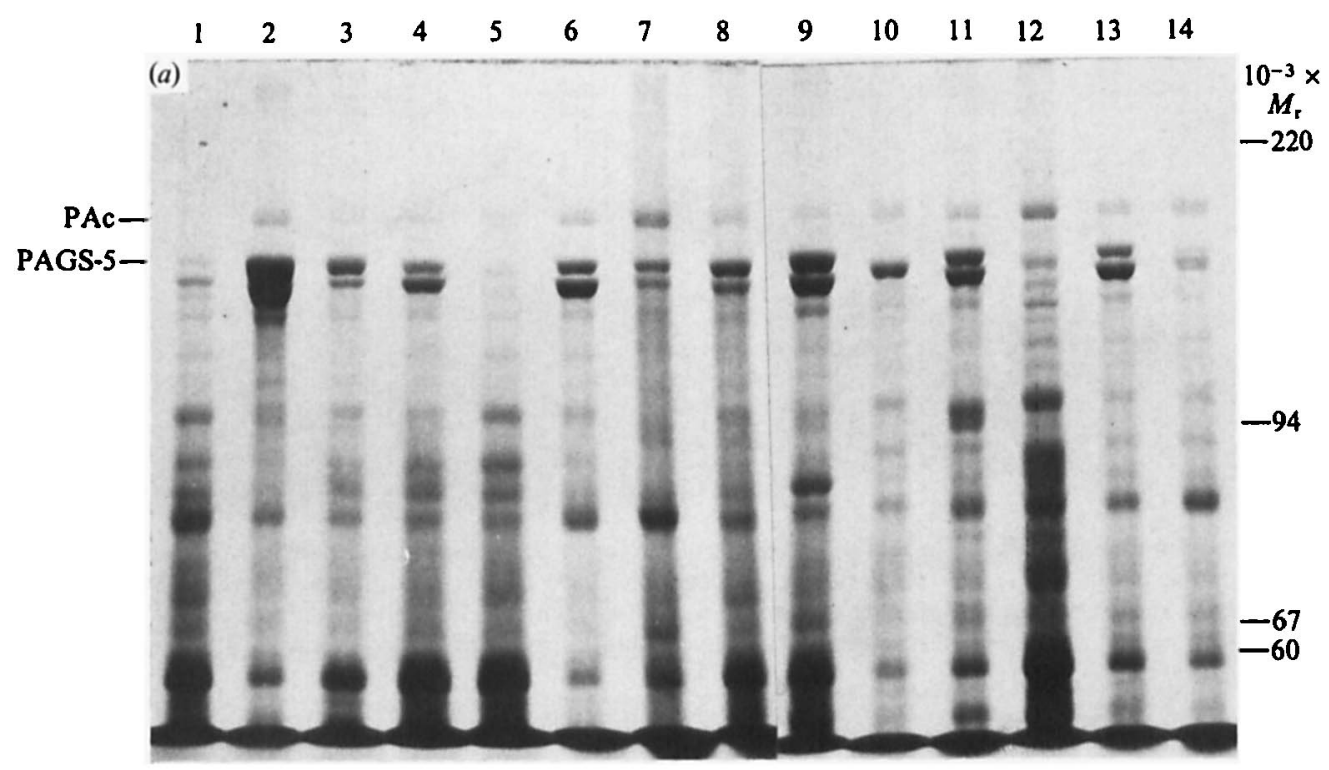

(b)

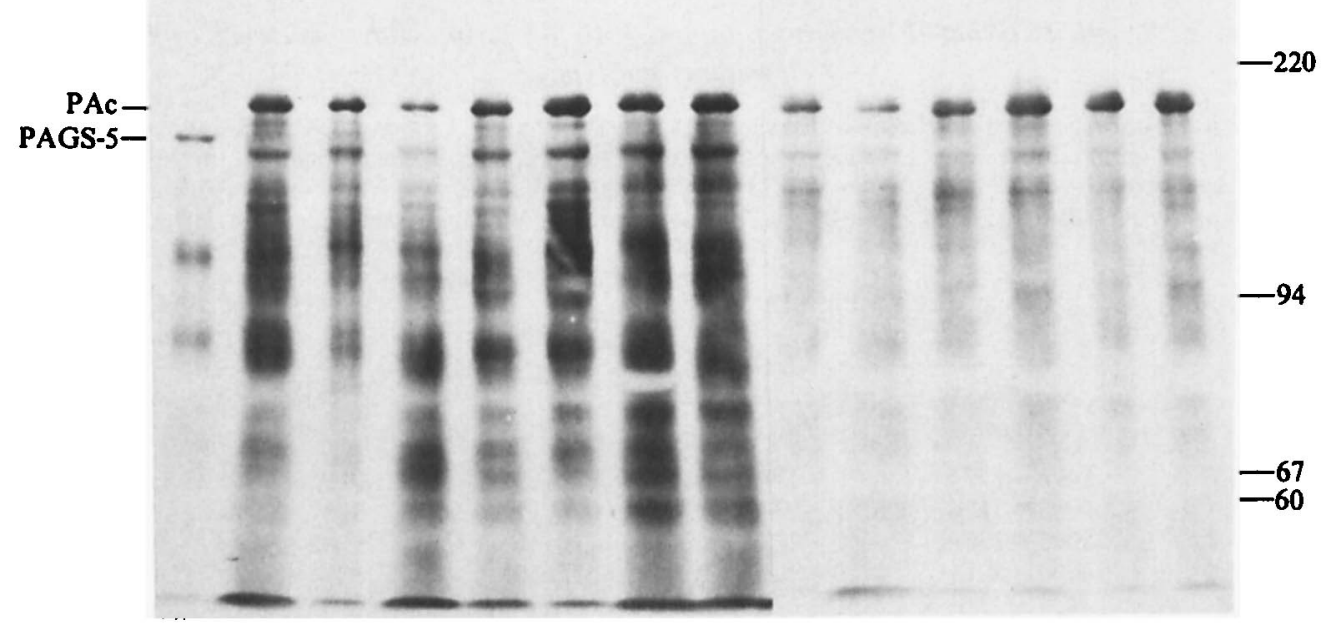

Fig. 2. SDS-PAGE and Western blotting of cell extracts of serotype $c S$. mutans strains. Whole cells were suspended in $8 \mathrm{M}$-urea, $1 \%(\mathrm{w} / \mathrm{v}) \mathrm{SDS}$ and $1 \%(\mathrm{v} / \mathrm{v}) 2$-mercaptoethanol, and heated at $100{ }^{\circ} \mathrm{C}$ for $3 \mathrm{~min}$. The cell extracts were clarified by centrifugation, and analysed by SDS-PAGE. (a) Gel stained with Coomassie brilliant blue. $(b)$ The antigens transferred on a nitrocellulose sheet were allowed to react with anti-PAc serum. For the lanes, see the legend for Fig. 1.

with rabbit anti-PAc serum. A small amount of PAGS-5 was present on the cell surface. Immunodiffusion analysis showed that PAGS-5 lacked a part of the antigenic moieties in the PAc molecule. Ayakawa et al. (1987) have recently reported that none of 15 murine monoclonal antibodies directed against antigen P1 (identical with PAc) reacted with whole cells of strain GS-5. The monoclonal antibodies isolated by Ayakawa et al. (1987) may be specific for a region of the PAc molecule that PAGS-5 lacks.

PAc is known to exist both in a form apparently closely associated with peptidoglycan of serotype $c S$. mutans strains and in their culture supernatants (Russell, 1979; Zanders \& Lehner, 

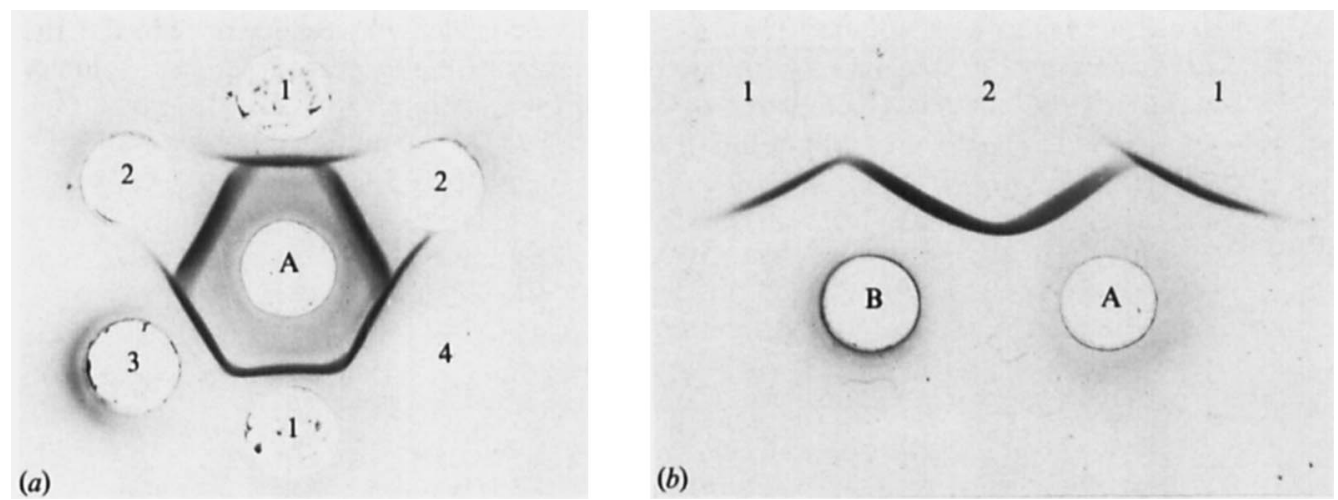

Fig. 3. Immunodiffusion of culture supernatants of serotype $c S$. mutans strains against anti-PAc serum (a) and anti-PAGS-5 serum (b). Well 1, concentrated culture supernatant of strain MT8148; well 2 , concentrated culture supernatant of strain GS-5; well 3, concentrated culture supernatant of strain Ingbritt; well 4, PAc purified from the culture supernatant of strain MT8148; well A, anti-PAc serum; well $B$, anti-PAGS-5 serum.

Table 2. Reactivity of anti-PAc serum and anti-PAGS-5 serum with whole cells of strains of $S$. mutans serotype $c$

$S$. mutans cells $\left(5 \times 10^{7}\right)$ were allowed to react with anti-PAc serum $(1 \mu \mathrm{l})$ or anti-PAGS-5 serum $(1 \mu \mathrm{l})$ for $1 \mathrm{~h}$ at room temperature. After being washed three times in PBS by centrifugation, the cells were allowed to react with ${ }^{125} \mathrm{I}$-labelled goat-anti-rabbit immunoglobulin $\mathrm{G}$ for $1 \mathrm{~h}$ at room temperature. The radioactivity associated with the cells was then determined. Values are the mean \pm SD of triplicate assays.

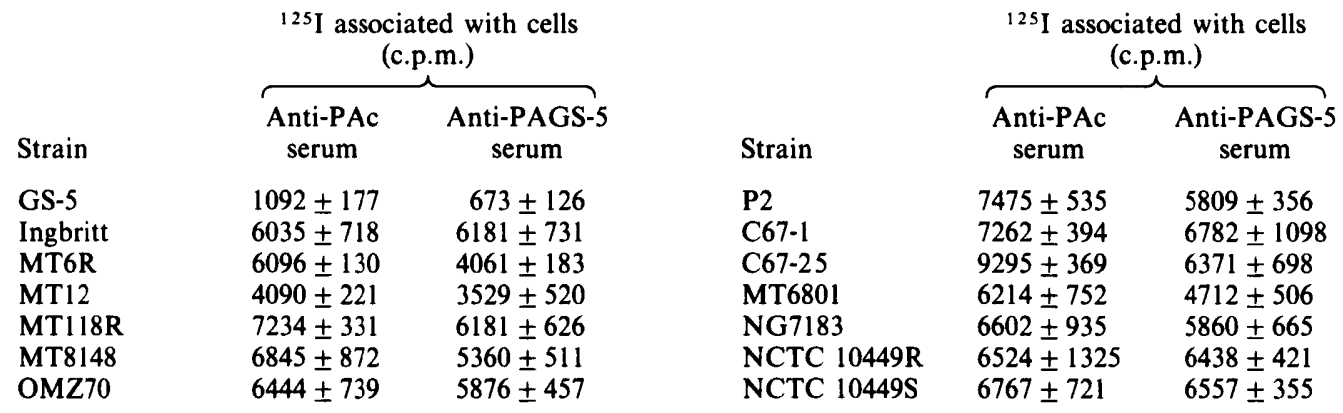

1981; McBride et al., 1984). In strain GS-5, PAGS-5 was predominantly found free in the culture supernatant. Hollingshead et al. (1986) have shown that type $6 \mathrm{M}$ protein of Streptococcus pyogenes is attached to the streptococcal cell through a proline-rich wall stabilization region and a membrane anchor region at the carboxyl-terminal end of the protein. It is possible that PAGS-5 lacks a region participating in linking to the cell wall of $S$. mutans. For verification of this hypothesis, we are presently attempting to clone the genes coding for PAc and PAGS-5 into Escherichia coli and to determine the nucleotide sequences of the genes.

There is currently great interest in the role of cell-surface hydrophobicity in mediating bacterial adherence to teeth and oral mucosal surfaces (Gibbons, 1984). Westergren \& Olsson (1983) isolated variant strains LK 36 and GW36, with decreased hydrophobicity, by repeated subculture of freshly isolated strains LK and GW, respectively, of $S$. mutans serotype $c$, and 
showed that the variant cells adhered less well to saliva-coated hydroxyapatite than did the parent cells. The variant strains were agglutinated to a lower extent by parotid saliva or salivary agglutinin than the parent cells (Rundegren \& Olsson, 1987). Moreover, McBride et al. (1984) have shown that cell extracts of hydrophobic strains LK and GW contain a number of high- $M_{\mathrm{r}}$ (mainly $M_{\mathrm{r}}$ 190000) proteins which are not present on cells of strains LK36 and GW36 with decreased hydrophobicity. Russell \& Smith (1986) have reported that the protein of $M_{\mathrm{r}} 190000$ altered in the LK strains is indeed antigen B. We confirmed that PAc also was immunologically identical to antigen B kindly supplied by Dr R. R. B. Russell (unpublished data). We have shown in this study that hydrophilic strain GS-5 did not produce PAc of $M_{\mathrm{r}} 190000$. These results support the suggestion of McBride et al. (1984) that the $M_{\mathrm{r}} 190000$ protein is important in surface hydrophobicity of $S$. mutans. In this connection, we should note that the amount of cellassociated PAc and surface hydrophobicity of serotype $c S$. mutans strains used in this study were not apparently correlated. Russell \& Smith (1986) similarly found that the hydrophobicity of $S$. mutans could not be correlated solely with PAc, but involved various other surface molecules such as other surface proteins and lipoteichoic acid. Therefore, it is difficult to rule out the possibility that other antigens not detected in this study may be altered in strain GS-5.

In conclusion, an $M_{\mathrm{r}} 190000$ protein antigen was present on cell surfaces of hydrophobic strains of $S$. mutans serotype $c$. Hydrophilic $S$. mutans strain GS-5 did not produce the high- $M_{\mathrm{r}}$ protein antigen, but produced extracellularly an $M_{\mathrm{r}} 155000$ protein antigen that lacked a region participating in binding to the streptococcal cell.

This work was supported in part by Grant-in Aid for Developmental Scientific Research (no. 63870086) from the Ministry of Education, Science and Culture of Japan.

\section{REFERENCES}

Ayakawa, G. Y., Boushell, L. W., Crowley, P. J., ERdos, G. W., McArthur, W. P. \& Bleiweis, A. S. (1987). Isolation and characterization of monoclonal antibodies specific for antigen P1, a major surface protein of mutans streptococci. Infection and Immunity 55, 2759-2767.

BURNETTE, W. N. (1981). 'Western blotting': electrophoretic transfer of proteins from sodium dodecyl sulfate-polyacrylamide gels to unmodified nitrocellulose and radiographic detection with antibody and radioiodinated protein A. Analytical Biochemistry 112, 195-203.

Forester, H., Hunter, N. \& KNox, K. W. (1983). Characteristics of a high molecular weight extracellular protein of Streptococcus mutans. Journal of General Microbiology 129, 2779-2788.

GibBons, R. J. (1984). Adherent interactions which may affect microbial ecology in the mouth. Journal of Dental Research 63, 378-385.

Hamada, S. \& Slade, H. D. (1980). Biology, immunology, and cariogenicity of Streptococcus mutans. Microbiological Reviews 44, 331-384.

Hollingshead, S. K., Fischetti, V. A. \& SCOtT, J. R. (1986). Complete nucleotide sequence of type $6 \mathrm{M}$ protein of the group A Streptococcus. Journal of Biological Chemistry 261, 1677-1686.

Holt, R. G., Abiko, Y., Saito, S., Smorawinska, M., Hansen, J. B. \& CuRTiss, R., III (1 982). Streptococcus mutans genes that code for extracellular proteins in Escherichia coli $\mathrm{K}-12$. Infection and Immunity 38, 147-156.

Hughes, M., Machardy, S. M., Sheppard, A. J. \& Woods, N. C. (1980). Evidence for an immunological relationship between Streptococcus mutans and human cardiac tissue. Infection and Immunity 27, 576-588.
Kato, H., Ota, F., Fukui, K. \& Yagawa, K. (1986). Monoclonal antibody to Streptococcus mutans type $e$ cell wall polysaccharide antigen. Infection and Immunity 52, 628-630.

Koga, T., Asakawa, H., OKahashi, N. \& Hamada, S. (1986). Sucrose-dependent cell adherence and cariogenicity of serotype $c$ Streptococcus mutans. Journal of General Microbiology 132, 2873-2883.

LAEMMLI, U. K. (1970). Cleavage of structural proteins during the assembly of the head of bacteriophage T4. Nature, London 227, 680-685.

Lehner, T., Russell, M. W., Caldwell, J. \& Smith, R. (1981). Immunization with purified protein antigens from Streptococcus mutans against dental caries in rhesus monkeys. Infection and Immunity 34, 407-415.

Lehner, T., Caldwell, J. \& Smith, R. (1985). Local passive immunization by monoclonal antibodies against streptococcal antigen $\mathrm{I} / \mathrm{II}$ in the prevention of dental caries. Infection and Immunity 50, 796799.

LOESCHE, W. J. (1986). Role of Streptococcus mutans in human dental decay. Microbiological Reviews 50, 353-380.

MA, J. K.-C., SMITH, R. \& LEHNER, T. (1987). Use of monoclonal antibodies in local passive immunization to prevent colonization of human teeth by Streptococcus mutans. Infection and Immunity 55, 1274-1278.

McBride, B. C., Song, M., Krasse, B. \& Olsson, J. (1984). Biochemical and immunological differences between hydrophobic and hydrophilic strains of Streptococcus mutans. Infection and Immunity 44, 6875.

MORO, I. \& Russell, M. W. (1983). Ultrastructural localization of protein antigens I/II and III in 
Streptococcus mutans. Infection and Immunity 41, 410-413.

Okahashi, N., Koga, T. \& Hamada, S. (1986). Purification and immunochemical properties of a protein antigen from serotype $g$ Streptococcus mutans. Microbiology and Immunology 30, 35-47.

Rundegren, J. \& OLsson, J. (1987). Interactions between salivary agglutinins and strains of Streptococcus mutans with varying degrees of surface hydrophobicity. FEMS Microbiology Letters 40, 141-146.

Russell, R. R. B. (1979). Wall-associated protein antigens of Streptococcus mutans. Journal of General Microbiology 114, 109-115.

Russell, R. R. B. \& SMITH, K. (1986). Effect of subculturing on location of Streptococcus mutans antigens. FEMS Microbiology Letters 35, 319-323.

RusSell, M. W., Bergmeier, L. A., ZANDERS, E. D. \& LEHNER, T. (1980). Protein antigens of Streptococcus mutans: purification and properties of a double antigen and its protease-resistant component. Infection and Immunity 28, 486-493.

Russell, R. R. B., Beighton, D. \& Cohen, B. (1982). Immunisation of monkeys (Macaca fascicularis) with antigens purified from Streptococcus mutans. British Dental Journal 152, 81-84.

Scully, C. M., Russell, M. W. \& LehNer, T. (1980). Specificity of opsonizing antibodies to antigens of Streptococcus mutans. Immunology 41, 467-473.

WESTERGREN, G. \& OLSSON, J. (1983). Hydrophobicity and adherence of oral streptococci after repeated subculture in vitro. Infection and Immunity 40, 432435.

ZANDERS, E. D. \& LeHNER, T. (1981). Separation and characterization of a protein antigen from cells of Streptococcus mutans. Journal of General Microbiology 122, 217-225. 